\title{
ЗМІНА ПОВІДОМЛЕННЯ ОСОБІ ПРО ПІДОЗРУ НА СТАДІЇ ДОСУДОВОГО РОЗСЛІДУВАННЯ
}

\author{
КУШПІТ Володимир Петрович - кандидат юридичних наук, доцент, \\ доцент кафедри кримінального права і процесу Навчально-наукового інституту \\ права, психології та інноваційної освіти Національного університету «Львівська \\ політехніка»
}

ORCID ID: 0000-0002-1664-6696

УДК 343.13

DOI 10.32782/LAW.UA.2021.4.15

Метою наукової статті є проаналізувати інститут повідомлення особі про підозру, який замінив собою систему законодавчих положень щодо притягнення особи як обвинуваченого на стадіӥ досудового розслідування. 3'ясовано, що повідомлення особі про підозру займає особливе місие у структурі етапів досудового розслідування, адже воно є початковим моментом притягнення особи до кримінальної відповідальності та визначає подальше спрямування кримінального провадження. Порушення органами досудового розслідування та прокурором прочесуальной борми, визначеної кримінальним прочесуальним законом при реалізаиї процедури повідомлення особі про підозру з підстав, визначених ч. $1 \mathrm{~cm} .276$ КПК, призводять не тільки до протизаконного та безпідставного обмеження прав учасників кримінального провадження, а ци у подальшому ставлять під сумнів можливість досягнення завдань кримінального провадження у изілому. Здійснено короткий огляд проблеми процесуального порядку повідомлення особі про підозру, гарантій забезпечення прав підозрюваного, що, у свою чергу, потребує їх грунтовного наукового осмислення та вирішення у практищі правозастосування органів досудового розслідування та прокуратури відповідно до процесуальної форми стадї̈ досудового розслідування.

Ключові слова:досудове розслідування, кримінальне правопорушення, повідомлення про підозру, докази, слідчий, прокурор.

\section{Постановка проблеми}

Досудове розслідування основним завданням має охорону прав та законних інтересів фізичних і юридичних осіб, які беруть участь у кримінальному провадженні, а також швидке, повне та неупереджене розслідування кримінальних правопорушень, викриття винних та забезпечення правильного застосування чинного законодавства, щоб кожний, хто вчинив кримінальне правопорушення, був притягнутий до відповідальності із застосуванням належної правової процедури, а жоден невинуватий не був покараний. Тільки проведення швидкого, повного та неупередженого досудового розслідування надасть суду можливість дослідити всі обставини вчиненого особою діяння і надати їм належну правову оцінку. Повідомлена особі підозра, що базується на зібраних під час досудового розслідування доказах, визначає межі судового розгляду. Однак, встановлюючи ці межі, слідчий, прокурор не обмежують розслідування провадження тільки один раз повідомленою підозрою.

Аналіз останніх досліджень і публікацій

Окресленим питанням приділялась увага у наукових працях: Ю. І. Азарова, Ю. П. Аленіна, С. А. Альперта, О. М. Бандурки, О. В. Бауліна, В. Д. Берназа, М. В. Жогіна, З. З. Зінатуліна, А. М. Аобойка, О. В. Капліної, А. М. Карнєєвої, В. Т. Маляренка, I. Є. Марочкіна, А. В. Молдована, О. Р. Ми- 


\section{Кримінальне право, кримінальний процес та криміналістика}

хайленка, А. Д. Удалової, Ф. Н. Фаткулліна, В. М. Юрчишина та інших.

\section{Виклад основних положень}

Подальше досудове розслідування провадження може виявити обставини, що спричинять зміну підозри або складання нової підозри. В ідеалі акт повідомлення про підозру є так званим підсумком досудового розслідування, оскільки саме на ньому базується обвинувальний акт, який після закінчення досудового розслідування відповідно до вимог ст. 291 КПК вручається підозрюваному.

Доречно зазначити, що у практичній діяльності найкращим бажаним варіантом для слідчих, прокурорів було б повідомлення особі про підозру наприкінці досудового розслідування, оскільки саме в цей час у матеріалах провадження знаходиться достатня кількість доказів для його направлення до суду і з'ясовані всі обставини вчиненого кримінального правопорушення, що дає змогу скласти так зване «зразкове» повідомлення про підозру, яке не потребує змін та доповнень.

Якщо повідомлення про підозру здійснюється у випадку, передбаченому п. 1 та п. 2 ч. 1 ст. 276 КПК, то зрозуміло, що відкласти повідомлення особі про підозру неможливо, але якщо розглядати випадок повідомлення особі про підозру на підставі наявності достатніх доказів для підозри особи у вчиненні кримінального правопорушення, то можливість складання та вручення повідомлення про підозру особі наприкінці досудового розслідування існує. Але такий варіант повідомлення про підозру особі, на нашу думку, не є прийнятним.

Обгрунтовуючи свою позицію, зазначимо, що у практичній діяльності під час досудового розслідування встановлюеться велика кількість нових фактів і доказів. Одні 3 них безпосередньо відносяться до провадження, інші - походять 3 перших і бувають певною мірою допоміжними. Це також стосується даних, що характеризують особу підозрюваного, потерпілого, свідків. Одні факти і докази слідчий та прокурор отримують уже на початковому етапі досудового розслідування, інші - через деякий час, під час проведення слідчих (розшукових) дій на подальшому етапі розслідування. Отже, ситуація у конкретному провадженні постійно змінюється, а з появою у кримінальному провадженні нових фактів та учасників процесу може змінюватися й обсяг підозри.

Також доцільно звернути увагу на той факт, що у разі повідомлення особі про підозру наприкінці досудового розслідування особа, яка фактично підозрювалась стороною обвинувачення у вчиненні кримінального правопорушення, щодо якої слідчий, прокурор збирали докази вини і фактично проти якої тривало досудове розслідування без вручення повідомлення про підозру, була позбавлена можливості захищатися від підозри у вчиненні цього кримінального правопорушення. Отже, несвоєчасне повідомлення особі про підозру у кримінальному провадженні порушить право підозрюваного на захист, позбавить можливості збирати і подавати докази, одержувати копії процесуальних документів та реалізації інших прав [1, с. 402].

Таким чином, умисне відкладання моменту повідомлення особі про підозру слідчим, прокурором наприкінці досудового розслідування є протиправним та незаконним.

Крім цього, слід зауважити, що вимога закону про повне та неупереджене розслідування кримінальних правопорушень не повинна трактуватися на користь багаторічного досудового розслідування кримінальних проваджень. Воно має бути проведене в об'єктивно необхідний для виконання процесуальних дій та прийняття процесуальних рішень термін, тобто в розумний строк, що є однією із засад кримінального провадження.

Зв’язаність слідчого вимогою швидкості проведення розслідування може призвести до помилкової кваліфікації злочинного діяння, повідомлення про підозру в момент, коли ще не всі необхідні для прийняття цього рішення дані зібрані, що іноді призводить до незаконного повідомлення про підозру невинуватої особи та до інших важких помилок.

У цьому випадку ми торкнулися питання ефективності провадження досудового 
розслідування, підсумком якого має бути доведена, неспростовна, чітка, об'єктивна та справедлива підозра. Для того, щоб стати таким, повідомлення про підозру неодноразово корегується, вмотивовується, змінюється.

Отже, під час досудового розслідування кримінального провадження, після повідомлення особі про підозру слідчим, прокурором можуть бути отримані нові докази або може бути надана інша оцінка вже відомим доказам, у зв’язку з чим до того моменту, як слідчим буде прийнято остаточне рішення у провадженні відповідно до вимог ст. 283 КПК, формула повідомлення про підозру, викладена в повідомленні про підозру та вручена підозрюваному, може: 1) залишитися без змін 3 точки зору як фактичних обставин вчинення кримінального правопорушення певною особою, так і їх юридичної оцінки; 2) зазнати певних змін; 3) містити нову підозру [1, с. 406].

Чинний КПК у ст. 279 пояснює, що у разі виникнення підстав для повідомлення про нову підозру або зміну раніше повідомленої підозри слідчий, прокурор зобов'язані виконати дії, передбачені ст. 278 КПК. Якщо повідомлення про підозру здійснив прокурор, повідомити про нову підозру або змінити раніше повідомлену підозру має право лише прокурор.

Виходячи 3 положень цієї норми, приходимо до висновку, що законодавець не тільки не розкриває сутність термінів «зміна підозри», «нова підозра», але навіть не зазначає випадків їх застосування, обмежившись лише посиланням «у випадку виникнення підстав». Отже, реалізація викладеної ст. 279 КПК у практичній діяльності не могла не викликати певних проблем.

Для розкриття питання зміни підозри в аспекті ст. 279 КПК потрібно з'ясувати підстави, за наявності яких відбувається зміна підозри або повідомляється нова підозра, а також визначити сутність понять «зміна раніше повідомленої підозри» та «нова підозра».

На нашу думку, зміна повідомлення про підозру у широкому розумінні цього поняття полягає у непідтвердженні частини повідомлення про підозру; доповненні пові- домлення про підозру; зміні повідомлення про підозру.

Непідтвердження частини повідомлення про підозру означає, що повідомлення про підозру за окремим епізодом чи самостійним діянням не підтвердилося; не дістала підтвердження кваліфікуюча ознака; не дістала підтвердження та чи інша дія у структурі окремого епізоду або діяння; виявилась зайвою кваліфікація діяння за сукупністю кримінальних правопорушень (за декількома статтями КК).

Непідтвердження частини повідомлення про підозру щодо окремого кримінального правопорушення або правопорушень найчастіше виникає внаслідок спростування будь-якої ознаки складу кримінального правопорушення, який інкримінується; самообмови підозрюваного; неякісного проведення досудового розслідування або слідчих (розшукових) дій; декриміналізації діяння.

Внаслідок непідтвердження частини повідомлення про підозру можуть виникнути ситуації, коли змінювати кваліфікацію не потрібно і коли це є необхідним, що зумовить складання нової підозри.

Доповнення повідомлення про підозру необхідне у тих випадках, коли у процесі розслідування, після повідомлення про підозру, з'ясовуються нові факти злочинної діяльності особи. Додаткові обставини можуть зумовити підозру у новому кримінальному правопорушенні або заміну підозри в одному кримінальному правопорушенні на підозру в іншому.

У юридичній літературі підставами доповнення обвинувачення (повідомлення про підозру) прийнято вважати випадки, коли: а) після обвинувачення з'ясувалося, що обвинувачений, крім інкримінованого, вчинив ще інше кримінальне правопорушення; б) у діях обвинуваченого, за вчинення яких його вже було притягнуто як обвинуваченого, виявляється самостійний склад кримінального правопорушення; в) з'ясувалося, що особа, яка притягується до кримінальної відповідальності, вчинила кримінальне правопорушення у співучасті 3 іншими особами, які до відповідальності не були притягнуті [2, с. 68]. 


\section{Кримінальне право, кримінальний процес та криміналістика}

Виявлення після повідомлення про підозру факту вчинення підозрюваним іншого кримінального правопорушення, крім інкримінованого, завжди призводить до зміни підозри шляхом його доповнення. При цьому може змінитися лише фабула підозри (викладені в повідомленні обставини кримінального правопорушення), якщо підозрюваним вчинено злочин, який кваліфікується за тією самою нормою КК, що й інкриміноване кримінальне правопорушення. Так, наприклад, після повідомлення особі про підозру за вчинення крадіжки 3 проникненням у житло, виявляється, що особа, крім того, вчинила ще аналогічну крадіжку. Фабула підозри доповниться, з'являється кваліфікуюча ознака повторності, але кваліфікація дій підозрюваного залишиться незмінною.

У разі включення до підозри іншого вчиненого підозрюваним кримінального правопорушення загальна кваліфікація його дій може змінюватися, якщо це правопорушення кваліфікується за іншою статтею (частиною статті) КК, ніж інкримінований. У такому разі доповниться фабула підозри, а також зміниться кваліфікація дій підозрюваного. При цьому може змінитися частина статті (за кваліфікуючою ознакою) або перелік статей може доповнитися ще однією статтею або частиною статті.

Виявлення у діях підозрюваного, крім кримінальних правопорушень, за вчинення яких йому вже була повідомлена підозра, самостійного складу кримінального правопорушення у кримінальній процесуальній практиці зустрічається не часто. Але у разі застосування п.п. 1, 2 ч. 276 КПК та негайного повідомлення особі про підозру, коли ще певні обставини на початковому етапі розслідування встановлюються, наприклад, за допомогою показань підозрюваного (потерпілого або свідка) і відразу іншими засобами перевірити їх неможливо, а під час подальшого розслідування ці показання спростовуються чи уточнюються, виникає необхідність змінити підозру.

Виявлення факту вчинення особою, якій повідомлено про підозру, кримінального правопорушення у співучасті з іншими особами, які про підозру не повідомлялись, безперечно, вплине на зміну підозри у бік іiі обтяження, оскільки фабула підозри у повідомленні про підозру доповниться детальним викладенням злочинних дій кожного iз співучасників кримінального правопорушення, а також кваліфікуючою ознакою вчинення кримінального правопорушення групою осіб. При цьому, як правило, стаття підозри залишається незмінною, а змінюється тільки їі частина, але й вона може залишитися незмінною. Зміна частини статті КК відбудеться за умови, що первинно дії підозрюваного кваліфікувалися за частиною першою певної статті КК, оскільки вчинення кримінального правопорушення групою осіб як кваліфікуюча ознака зазвичай міститься у другій або третій частині тієї самої статті КК. Якщо первинно дії підозрюваного кваліфікувалися за тією частиною статті, якою регламентується і кваліфікуюча ознака «вчинення злочину групою осіб», кваліфікація у разі доповнення підозри залишається такою самою.

Виявлення після повідомлення про підозру будь-яких обставин кримінального правопорушення чи відомостей про особу підозрюваного, які впливають на кваліфікацію його дій, також є підставою доповнення підозри. До таких фактів належать відомості про обставини кримінального правопорушення та особу підозрюваного.

Межа між уточненням підозри та його доповненням досить тонка. Ключовим моментом при вирішенні цього питання є правова оцінка нових фактів, виявлених після повідомлення особи про підозру.

Отже, доповнення повідомлення про підозру може привести до зміни кваліфікації. Тому слідчий, прокурор при необхідності доповнити повідомлення про підозру повинен скласти нове повідомлення особі про підозру та вручити їй це повідомлення.

Зміна повідомлення про підозру (у вузькому розумінні цього поняття) може зумовлюватися виявленням обставин, які змінюють характер відомостей, викладених у попередньому повідомленні про підозру. Можуть бути уточнені фактичні обставини вчиненого (місце, час, спосіб діяння, характер і розмір шкоди і т. ін.), виправлена раніше допущена помилка або неточність у формулюванні підозри. 
Так, уточнення даних про місце, час i спосіб вчинення кримінального правопорушення має вкрай важливе значення, і в усіх випадках ці дані повинні відображатися у формулюванні підозри. 3 питанням про місце і час кримінального правопорушення пов'язана можливість підозрюваного вказати на алібі або використати інші засоби захисту від підозри. Уточнення відомостей про способи вчинення кримінального правопорушення може взагалі поставити під сумнів вчинення його саме цією особою.

Конкретизацію фактичних обставин кримінального правопорушення, яка призводить до зміни сутності підозри, важливо відрізняти від випадків уточнення фабули підозри, що не $є$ зміною підозри, та від виявлення таких даних, які зумовлюють збільшення обсягу підозру.

Особливих проблем при виокремленні зміни сутності підозри від збільшення обсягу підозри на підставі конкретизації обставин кримінального правопорушення не виникає, оскільки збільшитися обсяг підозри може тільки за умови, що ці виявлені обставини кримінального правопорушення впливають на кваліфікацію дій підозрюваного. Тобто якщо виявлення таких обставин спричиняє появу кваліфікуючої ознаки або необхідність додаткової кваліфікації ще й за іншою нормою КК, то ми матимемо випадок збільшення обсягу підозри.

Зміна сутності підозри відбувається на підставі таких обставин, що призводять до зміни кваліфікації дій підозрюваного з однієї норми на іншу. Тим самим зміна сутності підозри відрізняється також і від простого уточнення фабули підозри, за якого кваліфікація у всіх випадках залишається незмінною.

Зміна кваліфікації дій підозрюваного може виникнути у результаті іншої оцінки доказів. Якщо, наприклад, з'ясується, що має місце незакінчене кримінальне правопорушення, а початкова стадія злочинної діяльності, діяння підозрюваного слід кваліфікувати, окрім як за відповідною статтею КК, так і за ст. 14, 15 КК (готування чи замах на злочин). У випадках, коли встановлено, що форма співучасті підозрюваних у вчиненні злочину не однакова, дії організаторів, під- мовників і посібників слід кваліфікувати відповідно до статті КК, а також за відповідною частиною ст. 27 КК.

При необхідності зміни повідомлення особі про підозру слід мати на увазі, що нове повідомлення про підозру має бути узагальненим і здійснюватися не в доповнення до попередніх повідомлень, а замість раніше складених. У цьому випадку раніше повідомлена підозра, яка залишається у матеріалах провадження, автоматично втрачає свою силу [2, с. 124].

Так, за твердженням А.М. Аобойка, нове обвинувачення (у нашому випадку повідомлення про підозру) - це одночасне ставлення особі первинного обвинувачення та іншого, самостійного кримінального правопорушення [3, с. 198].

А.М. Карнєєва висловила іншу позицію. Вона стверджує, що нова постанова про притягнення як обвинувачення має бути узагальненою і виноситися не в доповнення до попередніх постанов про притягнення як обвинуваченого, а замість раніше винесених постанов [4, с. 51]. У цьому випадку раніше повідомлена підозра, залишаючись у матеріалах кримінального провадження, втрачає свою силу, про що повинно бути зазначено у новому повідомленні про підозру.

На нашу думку, саме такий порядок дозволяє підозрюваному найповніше реалізувати своє право на захист, а також інші процесуальні права. Ознайомившись з актом, який містить повідомлення про підозру у повному обсязі, підозрюваний має можливість глибше і ясніше усвідомити сутність підозри, яку важко було б досягти, якби підозра була викладена в окремих повідомленнях про підозру в межах одного кримінального провадження. Наявність у цьому провадженні декількох чинних повідомлень про підозру щодо однієї особи може дезорієнтувати самого підозрюваного, прокурора, слідчого суддю і суд. Щоб таке не трапилось, нове повідомлення особи про підозру має бути мотивованим, тобто містити пояснення необхідності винесення нового узагальнюючого повідомлення та обов'язкове зазначення факту втрачання дії попереднього повідомлення. 


\section{Кримінальне право, кримінальний процес та криміналістика}

У зв’язку з реалізацією положень ст. 279 КПК постає й інше питання: яку назву повинне мати повідомлення про підозру, коли, наприклад, зміни в одному кримінальному провадженні настільки суттєві, що торкаються і зміни вже оголошеного повідомлення про підозру, і появи додаткових кримінальних правопорушень, за якими необхідно здійснювати визначене законодавцем «нове повідомлення про підозру», і закриття в окремій частині повідомленої підозри?

Виходячи 3 наведеного розуміння понять «нова підозра» та «зміна раніше повідомленої», у такому кримінальному провадженні підозра змінюється, оскільки до цього особі вже було повідомлено про підозру і частина змін стосується саме кримінальних правопорушень, де підозра вже була повідомлена. Але, з іншого боку, враховуючи наявність нових фактів, тобто інших кримінальних правопорушень, які попередньо об'єднані в одне провадження, виникає необхідність у повідомленні особі нової підозри. Яку ж процесуальну дію повинен вчиняти слідчий або прокурор: змінювати підозру чи повідомляти нову? Або взагалі складати два акти: перший - про зміну раніше повідомленої підозри, а другий - про нову підозру. Що взагалі треба розуміти як нонсенс! На жаль законодавець не дає відповіді на ці питання.

Тому сьогодні слідчі та прокурори вирішують цю проблему на власний розсуд: дехто змінюе підозру, інші повідомляють про нову, треті - повідомляють нові підозри, змінюють раніше повідомлені, а потім об'єднують кримінальні провадження, щоб уникнути названих проблем, зокрема й тих, про які ми згадували у першому розділі нашого дослідження. Як наслідок дій останніх, у кримінальному провадженні існує декілька окремих повідомлень про підозру і відсутнє єдине узагальнююче повідомлення про підозру, що у кінцевому результаті дезорієнтує підозрюваного й ускладнюе роботу слідчого, прокурора, слідчого судді, суду [2, c. 406].

Аналізуючи положення ст. 279 КПК, ми приходимо до висновку, що зміна раніше повідомленої підозри у будь-якому випадку спричиняє складання нової підозри. Знову постає питання: де ж та межа, яка відокремлює «нову підозру» від «зміни раніше повідомленої»?

Узагальнюючи вищевикладене, вважаємо, що чинні положення ст. 279 КПК не можуть залишатися у такому викладенні, оскільки розмежування законодавцем «зміни раніше повідомленої підозри» та «нової підозри» є недоцільним, навіть виходячи із сутності цих понять, змінена підозра вже $\epsilon$ новою підозрою. Так, нове повідомлення про підозру має здійснюватись у порядку, передбаченому ст. 276 - 278 КПК, без надання йому назви «нова підозра».

Крім цього, розмежування зазначених визначень не спричиняє за собою жодних процесуальних наслідків, а лише ускладнює процес реалізації цього положення у практичній діяльності, сприяючи створенню у кримінальному провадженні окремих повідомлень про підозру, які, насамперед, дезорієнтують підозрюваного та інших учасників кримінального процесу. Тому пропонуємо замінити ч. 1 ст. 279 КПК і викласти iї в наступній редакції: «У разі виникнення підстав для зміни повідомленої підозри слідчий, прокурор зобов'язаний виконати дії, передбачені ст. 278 цього Кодексу, і заново у повному об'ємі повідомити особу про підозру. Якщо повідомлення про підозру здійснив прокурор, змінити раніше повідомлену підозру має право лише прокурор, який здійснив таке повідомлення про підозру» $[2$, c. 406].

Вважаємо за доцільне звернути увагу ще на один проблемний аспект зміни підозри. Це зміна підозри, яка відбувається у бік ії пом'якшення. До підстав виникнення такої зміни слід віднести ситуації, коли має місце: непідтвердження підозри щодо окремого кримінального правопорушення або правопорушень; відпадання кваліфікуючої ознаки; зайва кваліфікація вчинку за сукупністю кримінальних правопорушень.

До цих підстав помилково було б віднести такі, як: непідтвердження будь-якої події кримінального правопорушення, що інкримінується підозрюваному; відсутність у діях особи складу кримінального правопорушення, оскільки вони є підставами виключення провадження досудового розслідування у 
провадженні в цілому, хоча за своєю сутністю схожі з підставами пом'якшення підозри, але за їх наявності підозра взагалі не може існувати, а тим більше - його зміна.

Деякі процесуалісти висловлюють думку про те, що коли постає необхідність зміни кваліфікації діяння обвинуваченого згідно 3 нормою КК, яка передбачає менш тяжке покарання, і при цьому фактична сторона обвинувачення залишається незмінною, тоді немає необхідності ні в закритті провадження у частині висунутого обвинувачення, ні у пред'явленні нового обвинувачення. У цьому випадку досить назвати нову кваліфікацію кримінального правопорушення в обвинувальному висновку [5, с. 18].

Свого часу Ф.Н. Фаткуллін висловлював думку, яка також полягала у спрощенні порядку зміни обвинувачення за умов, які передбачають менш сувору санкцію. Так, автор вважав, що досить винести спеціальну постанову про зміну обвинувачення і в найкоротший термін вручити іiі копію обвинуваченому [6, с. 25].

3 ним не погоджувався А.Я. Дубинський, який стверджував, що зміна кваліфікації, зокрема й така, що покращує становище обвинуваченого, є новим обвинуваченням, оскільки особа притягується як обвинувачений у вчиненні іншого кримінального правопорушення, а не того, який йому інкримінувався раніше. Тому обвинувачений має бути своєчасно поставлений до відома про нове обвинувачення, бо в іншому випадку порушується його право на захист [7, с. 26].

Ми погоджуємося 3 А.Я. Дубинським, оскільки дійсно без роз'яснення слідчим, прокурором сутності зміненої підозри підозрюваний може не розібратися у ній самостійно. На нашу думку лише оголошення повідомлення, що констатує зміну підозри та вручення підозрюваному копії повідомлення не забезпечить повною мірою реалізацію підозрюваним свого права на захист.

Як ми вже зазначали, сьогодні чинний КПК не передбачає процедуру закриття кримінального провадження у частині не підтвердження раніше повідомленої підозри, але це не означає, що цієї проблеми не існує.
У юридичній літературі має місце точка зору про те, що не завжди за умови відсутності частини обвинувачення (підозри) слід приймати рішення про часткове закриття провадження. Саме Ф.Н. Фаткуллін та Н.В. Жогін наводять приклад ситуації, коли при наявності фактичної фабули складного обвинувачення відбувається вилучення 3 неї окремих діянь або епізодів, які становили частину інкримінованого обвинувачення сукупного, повторного або збірного злочину. Вони зазначають, що в таких випадках слід приймати рішення про зміну обвинувачення, про вилучення з нього фактів, які не підтвердилися, і коли в цьому є необхідність, про перекваліфікацію злочинного діяння в частині, що залишилась [8, с. 148].

Ми вважаємо, що слідчий, прокурор повинні не просто констатувати факт зміни обставин, а й чітко пояснити, чим завершилось розслідування конкретного епізоду кримінального правопорушення, тому наявність лише повідомлення про зміну підозри або повідомлення про нову підозру не в повному обсязі відобразить сутність того, що відбувається.

У зв'язку з цим ми пропонуємо внести зміни до ст. 279 чинного КПК, доповнивши іï частиною другою такого змісту: «Якщо під час досудового розслідування кримінального провадження частина повідомленої підозри не дістала свого підтвердження, слідчий, а в разі повідомлення підозри прокурором - тільки прокурор, своєю постановою закриває провадження у цій частині повідомленої підозри в порядку, передбаченому статтями 283 та 284 цього Кодексу, про що оголошує підозрюваному, 3 обов'язковим роз'ясненням іiі сутності».

Надаючи детальний аналіз ст. 279 чинного КПК, необхідно звернути увагу і на таке позитивне положення: у випадку повідомлення про підозру прокурором, повідомлення про нову підозру або зміна раніше повідомленої підозри здійснюється лише прокурором. Отже, слідчий, виявивши нові обставини у матеріалах кримінального провадження, які будуть впливати, наприклад, на зміну кваліфікації діяння, повинен перед прокурором клопотати про необхідність зміни підозри. Вважаємо, що це свідчить 
про унеможливлення слідчим самостійно змінити кваліфікацію, що виключить маніпулювання, пов’язані зі зміною кваліфікації 3 тяжкого злочину на менш тяжкий і навпаки, та в кінцевому результаті сприятиме контролю з боку не тільки прокурора, а й відомчого керівництва щодо проведення належного досудового розслідування у цьому кримінальному провадженні.

\section{Висновки}

Підводячи підсумок, зазначимо, що ст. 279 КПК потребує невідкладного доопрацювання та внесення відповідних змін, що сприятиме виконанню основних завдань кримінального провадження, і вважаємо, що зміни та доповнення, викладені вище, можуть бути нами використані при удосконаленні нового КПК.

\section{Лiтература}

1. Фараон О. В. Зміна повідомлення про підозру в аспекті ст. 279 Кримінального процесуального кодексу України /О. В. Фараон // Юридичний вісник. 2014.№ 6. С. 402 - 406.

2. Черкова М. Ю. Зміна обвинувачення в кримінально- процесуальному праві України: дис. ... канд. юрид. наук: 12.00.09 //Ауганський державний університет внутрішніх справ. Ауганськ. 2006. 205 с.

3. Лобойко Л. М. Кримінально-процесуальне право. Курс лекцій : Навч. посіб. К.: Істина, 2007. 456 с.

4. Карнєєва Л. М. Залучення до кримінальної відповідальності. Законність і обгрунтованість. М., 1971. 133 с.

5. Гальперин И. М. Квалификация преступлений: Закон, теория и практика // Соц. Законность. 1989. № 9 С. 36.

6. Фаткуллин Ф. Н. Изменения обвинения. М., 1987. 164 с.

7. Дубинский А. Я., Сербулов В. А. Привлечение в качестве обвиняемого. К.: НИиРИО КВШ МВД, 1989. 56 с.

8. Жогин Н. В., Фаткуллин Ф. Н. Предварительное следствие в советском уголовном процессе. М. : Юрид. лит., 1965. 368 с.

\section{Kushpit Volodymyr CHANGE OF PERSON'S NOTIFICATION OF SUSPECTION AT THE STAGE OF PRE- EXAMINATION INVESTIGATION}

The purpose of the scientific article is to analyze the institution of notification of a person of suspicion, which has replaced the system of legislative provisions on bringing a person as a defendant at the stage of pre-trial investigation. It was found that the notification of a person of suspicion occupies a special place in the structure of the stages of pre-trial investigation, as it is the initial moment of bringing a person to criminal responsibility and determines the further direction of criminal proceedings. Violation by the bodies of pre-trial investigation and the prosecutor of the procedural form determined by the criminal procedural the law in the implementation of the procedure for notifying a person of suspicion on the grounds specified in Part 1 of Art. 276 of the CPC, lead not only to illegal and unjustified restriction of the rights of participants in criminal proceedings, but also further question the possibility of achieving the objectives of criminal proceedings as a whole. A brief review of the problem of the procedural procedure for notifying a person of suspicion, guarantees of the suspect's rights, which in turn requires a thorough scientific understanding and solution in the practice of law enforcement pre-trial investigation and prosecution in accordance with the procedural form of pre-trial investigation.

The main task of pre-trial investigation is to protect the rights and legitimate interests of individuals and legal entities involved in criminal proceedings, as well as prompt, complete and impartial investigation of criminal offenses, exposing the perpetrators and ensuring the correct application of applicable law. was prosecuted with due process and no innocent person was punished. Only a prompt, complete and impartial pre-trial investigation will enable the court to investigate all the circumstances of the act committed by the person and provide them with a proper legal assessment. The suspicion notified to the person, based on the evidence gathered during the pre-trial investigation, determines the boundaries of the trial. However, in setting these limits, the investigator and the prosecutor do not limit the investigation of the proceedings to a single suspicion.

We believe that the investigator, the prosecutor should not only state the fact of change of circumstances, but also clearly explain how the investigation of a particular episode of a criminal offense ended, so the presence of only a report of a change of suspicion or a new suspicion will not fully reflect the essence of what is happening. .

Keywords: pre-trial investigation, criminal offense, report of suspicion, evidence, investigator, prosecutor. 